\title{
IAMJ
}

INTERNATIONAL

AYURVEDIC

MEDICAL JOURNAL

\section{DIGESTIVE DISORDERS (ANNAVAHA SROTAS VYADHI) IN OLD AGE - ISSUES AND POSSIBLE SOLUTIONS}

\author{
Geeta Basantwani $^{2}$, Rajendra Prasad $^{2}$ \\ ${ }^{1}$ JR2, Department of Kayachikitsa, Faculty of Ayurveda, I.M.S., BHU, Varanasi, Uttar Pradesh, India \\ ${ }^{2}$ Professor, Department of Kayachikitsa, Faculty of Ayurveda, I.M.S., BHU, Varanasi, Uttar Pradesh, India
}

Corresponding Author:geetabasantwani22@gmail.com

\section{https://doi.org/10.46607/iamj1 109122021}

(Published Online: December 2021)

Open Access

(C) International Ayurvedic Medical Journal, India

Article Received:17/10//2021 - Peer Reviewed:30/10/2021 - Accepted for Publication31/10/2021

\section{Check for updates}

\begin{abstract}
Old age is the result of the natural process of ageing and the time to enjoy life. As at this time, we are almost free from all responsibilities. But it can be enjoyed only when one is free from major ailments otherwise it becomes a great burden on ourselves as well as on others too. Due to increased health awareness, the average age of people is increasing day by day and the advancement in medical science provides great help in this regard. Therefore, people live longer but the natural process of ageing and exposure to unfavourable things causes a lot of derangements and weakening of bodily systems and organs in old age. So, there is a great need for geriatric health care in dayto-day practice so that we can improve the quality of life of old age. Besides a lot of major health problems of old age like Heart Disease, Hypertension, Diabetics, Joint disorders, Dementia, Strokes, etc; some minor ailments are equally important as they are often the cause of many major ailments e.g., Gastric Upsets, Insomnia, Anxiety, etc.
\end{abstract}

Keywords: Digestive Disorders, Old age, Vriddhaavastha, Annavahasrotasvyadhi, Issues, Solutions, Agni 


\section{INTRODUCTION}

Ageing is a slow process that refers to the impact of time on the structure and function of various systems of the body. By age 50 or 60 , the changes clinically reflect functional limitations such as reduced muscle power, vision, memory, locomotory function or exertional breathlessness. Gradual decline in homeostasis and immune function predisposes them to infections, autoimmune diseases, malignancies and digestive problems. The nutritional status of older persons is commonly inadequate. ${ }^{[1]}$ The physiological features of normal ageing have been identified by examining disease-free populations of older people, to separate the effects of pathology from those due to time alone. ${ }^{[2]}$ Ageing affects all functions of the GI system i.e. motility, enzyme and hormone secretion, absorption and digestion. The GIS plays an important role in the processes like absorption and metabolism of drugs and so it is commonly affected by side effects. Hence, this article aims to focus on the common diseases which affect the elderly while emphasizing details of clinical presentation and management in which they significantly differ from the younger population. Ageing has important effects on the gastrointestinal (GI) tract. An increasing incidence and prevalence of GI disease in the elderly are important considerations due to the demographic trends towards such a population. ${ }^{[4]}$

In Ayurveda, gastrointestinal disorders are correlated with Annavahasrotovyadhi which includes diseases such as aruchi, aadhmana, chardi, vibandh, grahani, udarshool, ajeerna, amlapitta, etc. in old age i.e., Vriddhaavastha. These disorders occur due to weak digestive fire i.e., mandagni and ama. In old age, vatadosha is predominant and causes vishamaagni. Being healthy throughout the whole life is not only the person's need but also a basic right of a person. Agni is the important and basic phenomenon of life. The qualities of a healthy individual are mentioned in Ayurveda as the equilibrium of all the three Doshas viz. Vata, Pitta and Kapha; Normal state of agni i.e., Jatharagni, normal function of Dhatus Viz. Rasa, Rakta, Mamsa, Meda, Asthi, Majja, Shukra; Normal function of Malas viz. Purisha (faeces), Mootra (urine), Sveda (sweat) ${ }^{[5]}$

\section{MATERIAL AND METHODS:}

Literary review of digestive disorders from classical treatises like Charak Samhita, Sushrut Samhita and Ashtang Hridayam along with its modern correlation from the relevant textbooks, peer-reviewed articles and relevant websites.

\section{OBSERVATIONS:}

Causes: -

1. Incomplete denture-

Most old people lose their teeth one by one due to which they are unable to chew the food properly and the food is not digested well. This simple indigestion may lead to many other permanent diseases. Most important thing is that an old person cannot eat fiber containing food items such as fruits and vegetables which are necessary for proper bowel evacuation. Instead of which they take more liquid diets and juices etc. leading to constipation and related problems. OSC i.e., Oral Sensorial Complaints are more prevalent in the elderly than in those of age $<65$, with $50 \%$ of the elderly reporting at least one of the Oral Sensorial complaints.

2. Physical disabilities-

Old people often suffer from physical disabilities that may be due to different types of arthritis or paralytic disorders. Osteoarthritis is a very common form of arthritis in older people and the most frequent cause of physical disability too. So, they are unable to move and walk normally and sufficiently. Lack of body movement does not support digestion of taken food. As in erect posture and during walking, the peristaltic movements took place in the right manner thereby pushing forward the food, gases and another thing. So, these disabilities may cause a lot of digestive disorders. ${ }^{[6]}$

3. Chronic Diseases-

Many chronic diseases cause a lot of gastrointestinal problems in elderly people. A few of them are as follow: 


\section{A) Heart Disease-}

Every heart problem can create gastrointestinal disturbances. The most common type of heart failure i.e., Congestive Heart Failure is a major cause of Chronic G.I. disorders.

Symptoms of gastrointestinal issues concerning cardiovascular disease:

- Intestinal angina- People lose a significant amount of weight due to the pain and problems which are associated with eating. The symptoms of intestinal angina include GI issues i.e., diarrhoea, nausea and vomiting followed by meals.

- Acute Intestinal Ischemia- This occurs when a blood clot is lodged in one of the intestinal arteries, as such clots usually originate in the heart and are caused by Atrial Fibrillation. ${ }^{[7]}$

- Congestive Gastropathy and Congestive Hepatomegaly in CHF patients- Common gastrointestinal manifestations of Heart Failure include anorexia, abdominal pain and early satiety.

In patients with advanced Heart Failure - ascites, protein-losing enteropathy (PLE). ${ }^{[8]}$

B) Diabetics Mellitus-

Uncontrolled diabetics cause different pathy at different sites by the process of Glycosylation of tissues. In this way, it may cause Gastropathy that leads to many gastrointestinal symptoms e.g., indigestion, flatulence, etc. In long term, the tone of the large bowel diminishes and results in constipation. Diabetic gastroparesis manifests as abdominal pain, bloating, vomiting, early satiety. ${ }^{[9]}$

4. Drug's side effects:

Every drug has its more or less unwanted effects in addition to required effects. Anyone can suffer from some disease at any age for which he or she takes some medicine. If any drug is taken for some illness for a smaller time, then one has to suffer from its side effects for a smaller duration and it does not affect the body anymore. This is a normal phenomenon in any age for regular illnesses.

Contrary to this in old age, people suffer from chronic illnesses for which they have to take medicine for a longer duration, sometimes lifelong. Besides this, the body tolerance of elderly people reduces naturally, thereby side effects cause more damages to their body. Among different systems, the gastrointestinal system gets more affected because this is the system to be exposed first as most drugs are taken by oral route. Troubles given by them are Hyperacidity, Refluxesophagitis, Gastritis, Pain in the abdomen, Flatulence, Constipation, Diarrhea, etc.

After G.I.T. liver is the next important organ to be involved as most drugs gets metabolized in it to change into an active form. In longer duration, they cause hepatic impairment and may cause serial of problems in addition to very common- anorexia. Any part of the gastrointestinal (GI) tract i.e., from mouth to colon can have adverse drug effects. ${ }^{[10]}$

\section{Diet restriction-}

A normal and balanced diet along with fiber supplements and sufficient water intake is necessary for proper digestion and evacuation. But in old age there are so many diet restrictions for different chronic illnesses e.g., diabetics cannot take carbohydrates freely, hypertensive people are advised to take a saltrestricted diet, cardiac patients are not permitted to take fats and similarly the renal and hepatic compromised patient takes protein, fat and salt-restricted diets.

These restrictions not only reduce the nutritional value of the diet, but their absence also diminishes the taste, flavour and palatability of food. So, after all, needs, older people consume a lesser amount of diet and leads to undernutrition, poor digestion and altered bowel habits. Effects of nutrition on disease processes for conditions including gastroesophageal reflux, inflammatory bowel disease and functional gastrointestinal disorders. ${ }^{[11]}$

6. Poor sleep-

Many elderly people suffer from Insomnia naturally or without any cause whereas many are unable to take sound sleep due to some illnesses e.g., Arthritis, Dyspnea, Cough, Hypertension or Stress. Proper and sound sleep is necessary for the fair working of every system of the body, the digestion too. In absence of proper sleep, one can suffer from simple indigestion to hyperacidity, flatulence and constipation also. Alterations in normal sleep patterns are thought to be a 
significant contributor to a vast array of illnesses including depression, metabolic syndrome, inflammation, gastrointestinal diseases, and also cancer. ${ }^{[12]}$

\section{AYURVEDIC CONCEPT:}

Normal equilibrium of Vata, Pitta and Kapha is necessary for the proper and ideal functioning of all body systems. But the status of Vata, pitta and Kapha changes from time to time, which may be normal or pathological. The different status of these doshas is very well described in ayurvedic texts with relation to today and night, mealtime, age factors, etc. These Tridoshas will also damage their functions when they become vitiated by Mithyaahaaravihaaras. Hence, tridoshas alone are the main causes for all the diseases ${ }^{[13]}$ According to which, Vata dosha is dominant in old age i.e., diseases of Vataja nature affects more in old age. ${ }^{[14]}$

Agni, literally fire, refers to the fire-like activity in the alimentary canal, responsible for the digestion of food. SamanaVayu, if normal, kindles the fire otherwise makes it irregular. Grahani dosha means a defect in agni situated in grahani. ${ }^{[15]}$ The optimum level of Jatharagni is important for normal digestion. But the altered positions of doshas changes the level of jatharagni thereby the digestion according to their gunas. Aggravated vata causes Vishamagni in all ages. As in old age, Vata is already dominant, so Vishamagni causes many digestive problems. The person suffering from Vishamagni gets Vibandha (constipation), adhmaan (flatulence), shoola (pain in the abdomen), etc. and this ajeerna is called Vishtabdhajeerna which causes Vatavyadhi's. ${ }^{[16]}$ The word Vishama means irregular. Vishamagni digests the food sometimes properly and sometimes improperly. Vishamagni is influenced by Vatadosha and hence is unpredictable in nature. When it is not digesting food properly, it produces flatulence, colic pain, heaviness, upward movement of Vayu, diarrhoea, heaviness and gurgling sound in the abdomen and tenesmus. If a person is suffering from such discomforts even after consuming balanced and regular food, then Agni is thought to be as Vishamagni. ${ }^{[17]}$ Along with vishamagni, mandagni is also equally predominant in old age. Due to this, the digestive sys- tem becomes a very dull, poor, inadequate and small quantity of food even gets digested after a very long time. In old age, with the predominance of Vata, the bowel movement is hard i.e., hard sabulous faeces being eliminated with difficulty and not regularly every day due to the krura nature of kostha.

Besides this, many other factors are also responsible for the aggravation of vata during old age. In arthritis, vata is involved, in hypertension, vata disturbs the normal flow of rakta, diabetics Mellitus is a type of vatajaprameha, myocardial infarction is typically vatajahridroga. So, these all affect body systems in any way and the digestion too directly and indirectly. Insomnia i.e., Ratrijagaran is highly responsible for vataprakopa and cause vibandha in addition to so many other problems such as adyaman, amlapitta, shool, etc. In ayurvedic texts, 80 types of vatavyadhis are mentioned. Among them, many are related to the digestive system, which may affect old people more commonly.

\section{TYPES OF GASTRIC UPSETS:}

1. Anorexia (Aruchi)

2. Indigestion (Ajeerna)

3. Hyperacidity (Amlapitta)

4. Flatulence (Adyaman)

5. Constipation (Vibandh)

6. Chronic diarrheal diseases (JeernaAtisar/ Grahani)

7. Colic Pain (Udarshool)

\section{DISCUSSION}

Considering an increase in life expectancy which leads to a rise in the elderly population, it is important to find out the changes that occur along the process of ageing. Gastrointestinal (GI) issues in elderly people are common, and despite some GI disorders which are more prevalent in the elderly, there is no such GI disease that is limited to this age group.

By considering all the factors one by one, we can avoid most of them.

1. Dental care is not a big or costly job. Wearing dentures is not necessary only because of cosmet- 
ic purposes, but it is very important for proper mastication of food and thereby for digestion too.

2. Physical disabilities should be properly taken care of. If they are not completely curable then by giving proper instructions and measures, their quality of life must be improved.

For example - Commode can be advised to people who are unable to bend their limbs due to arthritis and walkers should be given to paralytic patients for possible movements whereas ground floor living is beneficial for both of them.

3. Chronic and permanent diseases should be cured and controlled properly to avoid their complications e.g., controlled blood sugar in diabetics may avoid gastropathy. While prescribing medicines in elderly people; the dose, combination and preparation of drugs should be watched well so unwanted overloading and side effects of a drug can be prevented. While treating chronic illnesses, special care should be taken for the digestive system as it will hamper the nutrition of old people also, which is highly important for healthy living.

4. Diet restriction is necessary for controlling diseases. But nowadays, many better options and supplements are available, with the use them patients can maintain their taste and nutrition both without compromising their pathyaapathya.

For example, many low calorie and sugar-free supplements are available in the market to add taste to food without raising blood sugar levels. Similarly low sodium salt is available for hypertensives and suitable fat and oils are available for cardiac patients too. When the question arises for fiber supplements, then nowadays drinkable preparations are freely available that can be taken by people who have lost their denture also.

5. Sleep is very important for physical and mental wellbeing. If this is not normal in anyone, then firstly its causes should be treated so that natural sleep can be taken.

\section{CONCLUSION}

Health care in elderly people merits wide-ranging services and should focus on being comprehensive to meet the challenges of an increasingly dependent population. The management of elderly individuals who suffer from Gastrointestinal disease possesses a unique challenge. It is many times confusing part for us that which changes in Gastrointestinal function represents part of normal ageing processes and which of them are pathological results of a disease process. There is a lack of research on such a topic and available literature is commonly confusing. The management of GI diseases in the elderly, i.e., diagnostic algorithm as well as a therapeutic intervention, is also complicated by the frequent presence of comorbidities and a life expectancy that is limited. Deepening our knowledge is necessary in order for us to be able to provide better evidence-based and cost-effective care in order to increase the quality of life of such a patient population.

\section{REFERENCES}

1. API Textbook of Medicine, Chapter 27, Miscellaneous, 2. Geriatic Medicine, $7^{\text {th }}$ edition, page no 1459 1460.

2. Davidsons Principles and Practice of Medicine, Chapter 7, Ageing and disease, $2014,22^{\mathrm{ND}}$ edition , page no 169.

3. Dumic I, Nordin T, Jecmenica M, StojkovicLalosevic M, Milosavljevic T, Milovanovic T. Gastrointestinal Tract Disorders in Older Age. Can J Gastroenterol Hepatol. 2019; 2019:6757524. Published 2019 Jan 17. doi:10.1155/2019/6757524

4. D'Souza AL. Ageing and the gut. Postgrad Med J. 2007;83(975):44-53. doi:10.1136/pgmj.2006.049361

5. Sushruta, Sushrutasamhita, Nibandasangraha commentary sutra, 15/41, Chaukhambha Sanskrit sansthan, Varanasi, ed: 2010, page no 75.

6. www.nia.nih.gov>health>osteoarthritis

7. www.premierheartandveincare.com $>$ heart diseases

8. Levine B, Kalman J, Mayer L, Fillit HM, Packer M. Elevated circulating levels of tumour necrosis factor in severe chronic heart failure. $N$ Engl J Med. 1990; 323:236-241. doi: 10.1056/NEJM199007263230405. 
9. Krishnan B, Babu S, Walker J, Walker AB, Pappachan JM. Gastrointestinal complications of diabetes mellitus. World J Diabetes. 2013;4(3):51-63. doi:10.4239/wjd. v4.i3.51

10. Makins R, Ballinger A. Gastrointestinal side effects of drugs. Expert Opin Drug Saf. 2003 Jul;2(4):421-9. doi: 10.1517/14740338.2.4.421. PMID: 12904098.

11. Present Knowledge in Nutrition, $11^{\text {th }}$ edition, Vol-2 (Clinical and Applied Topics in Nutrition), Chapter23, Nutrition and gastrointestinal disorders, page no 413.

12. Ali T, Choe J, Awab A, Wagener TL, Orr WC. Sleep, immunity and inflammation in gastrointestinal disorders. World J Gastroenterol. 2013;19(48):9231-9239. doi:10.3748/wjg. v19.i48.9231

13. Sareera Kriya Vignanam (Physiology in Ayurveda) by Dr. M. Rama Sunder Rao, Chapter no 4 - Doshas, Dhatus and Malas, $4^{\text {th }}$ edition, page no 57.

14. Ashtanga Hrdayam by Prof. K. R. Srikantha Murthy, Sutrasthana Chapter 1, shlok no 8,9 Chowkhamba Krishnadas Academy, Varanasi, 10 ${ }^{\text {th }}$ edition, 2014, (page no 6,7)

15. Charaka Samhita by Prof. Priyavat Sharma, chikitsasthana 15/1, Chaukhambha Orientalia, Varanasi, $8^{\text {th }}$ edition 2007, page no 156 .

16. Sareera Kriya Vignanam (Physiology in Ayurveda) by Dr. M. Rama Sunder Rao, Chapter no 12 Annavaha Srotas, $4^{\text {th }}$ edition, , page no 137.

17. Sushruta, Sushrutasamhita, Nibandha Sangraha commentary sutra, 35/24, Chaukhambha Sanskrit sansthan, Varanasi, ed: 2010, page no 154.

\section{Source of Support: Nil \\ Conflict of Interest: None Declared}

How to cite this URL: Geeta Basantwani \& Rajendra Prasad: Digestive Disorders (Annavaha Srotas Vyadhi) In Old Age Issues And Possible Solutions. International Ayurvedic Medical Journal \{online\} 2021 \{cited December 2021\} Available from: http://www.iamj.in/posts/images/upload/2993_2998.pdf 